Ophthal. Res. 1977;9:I-VI

\title{
Contents, Vol. 9, 1977
}

\section{Contents}

No.1

Brix, F.: Determination of the Transmission of Corneas in situ by Means of Extinc tion Measurements 1

Chioralia, G.; Baurmann, H.; Dragomirescu, V.; Schomacher, L., and Valenzuela, H.: Experimental Fluorescein Findings in Rat Eyes after Retinal Laser Coagulation. Differences between Single Spot and Multiple Spot area Application 9 Rover, J. and Schaubele, G.: A Soft Contact Lens for DC Registration of the Human ERG 14

Wilke, K.: Intraocular and Episcleral Venous Pressure during Loading of the Eye in Pregnant and Non-Pregnant Women 19 Hudomel, J.; Nemeth, B.; Palfalvy, M., and Farkas, A.: Effect of Calcium Dobesilate $\left(\right.$ Doxium $\left.{ }^{\circledR}\right)$ on Blood Hyperviscosity in Cases of Diabetic Retinopathy 25 Koch, H.-R.; Kremer, F.; Hockwin, O., and Kaufmann, H.: Formation of Radiation Cataracts in Rats after Monolateral Carotid Ligature. Biochemical Results 31

Thaler, A. and Heilig, P.: EOG and ERG Components in Ischemic Retinopathy 38 Levett, J. and Ranganathan, N.: Temperature-Dependent Linearization Tech niques in the Retinal Response to Light 47 Hoek, L. D. van and Thijssen, J. M.: Contributions of Luminosity and Color Con trast to the Steady State Evoked Response $\quad 54$

Short Communication

MacKeen, D.L.: Response to the Report 'Influence of Soft Contact Lens Solutions on Rabbit Cornea' by Dreifus and Wobmann 62

No. 2

Srinivasan, B. D.; Worgul, B. V.; Iwamoto, T., and Merriam, G. R. jr. : The Conjunctival Epithelium. II. Histochemical and Ultrastructural Studies on Human and Rat Conjunctiva 65

Meretoja, J. and Tarkkanen, A.: Occurrence of Amyloid in Eyes with Pseudoexfoliation 80

Zigler, J.S. jr. and Sidbury, J.B. jr.: Studies on Lens Proteins from the Smooth Dogfish. Evidence for Evolutionary Conservatism in Vertebrate /?-Crystallin 92

Mester, U.; Stein, H. J., and Koch, H.-R.: Experimental Lens Opacities in Rabbits Induced by Intraocular Application of Acetylcholine Martenet, A.-C.: Antibodies to Uvea in the Eye 106 Momeni, M.H. and Muggli, F.M.: Progression of 22ßRa-Induced Ocular Altera tions in Beagles (with 1 color plate) 112

IV

Contents

Harding, J. J.: High Molecular Weight Fraction from Human Lens 
Rink, H.; Münnighoff, J., and Hockwin, O.: Sodium, Potassium and Calcium Contents of Bovine Lenses in Dependence on Age 129

Announcement $\quad 136$

No. 3

Cintron, C. and Kublin, C.L.: Microcrystalline Collagen and Corneal Wound Healing 137

Maisel, H.; Alcala, J.; Lieska, N., and Rafferty, N.: Regional Differences in the Polypeptide Composition of Chick Lens Intracellular Matrix 147

Bolkova, A. and C1/8jková, J.: Species Variation of Some Acid Hydrolases in the Normal Cornea $\quad 155$

Marak, G.E. jr.; Font, R.L., and Alepa, F.P.: Arthus-Type Panophthalmitis in Rats Sensitized to Heterologous Lens Protein 162

Sery, T. W. and Foster, L.: Viremia Induction of Herpes Simplex Uveitis 171

Ohrloff, C; Hockwin, O.; Jung, C, and Bours, J.: Enzyme Heterogeneity of

Aldolase Reductase (EC 1.1.1.2), Sorbitol Dehydrogenase (EC 1.1.1.14) and

Ketohexokinase (EC 2.7.1.3.) in Bovine Lenses 181

Koch, H.-R.; Fischer, A., and Kaufmann, H.: Occurrence of Cataracts in Spon taneously Hypertensive Rats 189

Imai, K.: Cholinergic Innervation of the Choroid 194

Bours, J.; Vassileva, P. I., and Hockwin, O.: Lactate Dehydrogenase Composition of the Rabbit Retina and Choroid after Ischemia Caused by Ligature of the Optic Nerve 201

No. 4

Keller, H.W.; Koch, H.-R., and Ohrloff, C.: Experimental Arabinose Cataracts in Young Rats 205

Praus, R. andKREjcí, L.: Tetracycline: Release from Hydrophilic Gel Contact Lens and Intraocular Penetration 213

Huber, C.: Evaluation of Pigmentary Dystrophy of the Retina by Visual Evoked Cortical Potentials to Sine Wave Modulated Light 217

Hess, R. F.: Eye Movements and Grating Acuity in Strabismic Amblyopia 225 Bucci, M.G.: Effects of New Topical /5-Mimetic (Isoxuprine and Nylidrine) and 1ß-Lytic (Oxprenolol) Agents on the Ocular Pressure in Glaucomatous Eyes ... 238 Contents

$\mathrm{V}$

Maistrello, I.; Rigamonti, G., and Ruggieri, P. de: Direct Measurement of In traocular Pressure in the Rat 247

Hata, N. and Hockwin, O.: Enzymatic Determination of Reduced and Oxidized Glutathione in Bovine Lenses of Different Ages and Their Distribution in Lens Equator and Nucleus 256

Truscott, R. J. W.; Faull, K., and Augusteyn, R. C.: The Identification of Anthranilic Acid in Proteolytic Digests of Cataractous Lens Proteins 263

No. 5

Coulter, J.B., III and Knebel, R.L.: Entry of Insulin into Aqueous Humor of

Rabbits After Feeding 269

Van Buskirk, R. G.: Ultrastructural Observations of Wound Healing in the Lens Epithelium of Hypophysectomized Frogs 276 
Maayani, S.; Treister, G., and Sokolovsky, M.: Drugs Affecting the Cholinergic System in the Intact Mammalian Eye. II. Cholinesterase Inhibitors 289 Unakar, N.J.; Weynsieder, A., and Reddan, J.R.: Ultrastructural Changes Associated with the Induction and Reversal of a Chemically Induced Cataract. 296 Landwehr, G.; Dietrich, K.; Weber, H.; Buschmann, W., and Neubauer, H.: Experiments with Pulsed Magnets for the Extraction of Intraocular Foreign Bodies 308

Marak, G.E., jr.; Font, R.L., and Ward, P.A.: Fluorescent Antibody Studies in Experimental Lens-Induced Granulomatous Endophthalmitis $\quad 317$ Missotten,L. and Goethals,M. : Timolol Reduces the Standing Potential of the Eye 321 Thaler, A.; Heilig, P., and Scheiber, V.: Fast Oscillation of the Corneoretinal Potential in Ischemic Retinopathy 324 Gorthy, W.C.: Cataracts in the Aging Rat Lens. Their Morphological Charac terization and Evaluation as a Model for Human Senile Cataracts 329 Nguyen-Legros, J. and Berger, B.: In vitro Catecholamine Uptake by DarkAdapted Rat Retina 343

Kaitz, M. and Auerbach, E.: Effect of Continuous Light Exposure on the Electroretinogram of Albino Rats 351

No. 6

Francois, J.; Victoria-Troncoso, V., and Zagorski, Z.: Histo-Enzymological Study of Normal and Pathological Keratocytes in Tissue Culture (Macular Dystrophy of the Cornea), (with 1 color plate) 357

Ensink, F.T.E. and van Haeringen, N. J.: Pitfalls in the Assay of Lysozyme in Human Tear Fluid 366

VI

Contents

Hazlett, L.D.; Rosen, D.D., and Berk, R.S.: Experimental Pseudomonas Keratitis in Immunosuppressed Hybrid Mice 374

Hong-Ming Cheng and Chylack, L.T., jr.: Factors Affecting the Rate of Lactate Production in Rat Lens $\quad 381$

Worgul, B.V.; Iwamoto, T., and Merriam, G.R., jr.: RNA-Containing Cytoplasmic Inclusions at the Termini of Maturing Fibers in the Rat Lens 388 Watson, R.R.: Presence and Development with Age of Aminopeptidase(s) in Tears of Children and other Mammals 397

Fowlks, W.L. and Wedekind, T.D.: Chloride Transfer from the Blood into and Fluxes within the Rabbit Eye 404

Marak, G.E., jr.; Font, R.L.; Alepa, F.P., and Ward, P.A.: Effects of C3 Inactivator Factor on the Development of Experimental Lens-Induced Granulomatous Endophthalmitis $\quad 416$

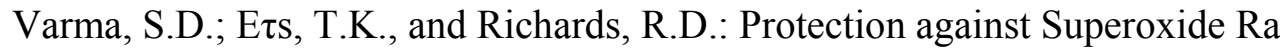
dicals in Rat Lens 421

Author Index 432

Subject Index

433 